\title{
The photosynthetic and structural differences between leaves and siliques of Brassica napus exposed to potassium deficiency
}

Zhifeng Lu', ${ }^{1,2}$ Yonghui Pan ${ }^{1}$, Wenshi Hu${ }^{1}$, Rihuan Cong ${ }^{1}$, Tao Ren ${ }^{1 *}$, Shiwei Guo ${ }^{2}$ and Jianwei Lu ${ }^{1}$

\begin{abstract}
Background: Most studies of photosynthesis in chlorenchymas under potassium (K) deficiency focus exclusively on leaves; however, little information is available on the physiological role of $\mathrm{K}$ on reproductive structures, which play a critical role in plant carbon gain. Brassica napus L., a natural organ-succession species, was used to compare the morphological, anatomical and photo-physiological differences between leaves and siliques exposed to K-deficiency.

Results: Compared to leaves, siliques displayed considerably lower $\mathrm{CO}_{2}$ assimilation rates $(A)$ under $\mathrm{K}$-deficient $(-\mathrm{K})$ or sufficient conditions $(+K)$, limited by decreased stomatal conductance $\left(g_{s}\right)$, apparent quantum yield $(a)$ and carboxylation efficiency (CE), as well as the ratio of the maximum rate of electron transport $\left(J_{\max }\right)$ and the maximum rate of ribulose 1,5-bisphosphate (RuBP) carboxylation $\left(V_{c \max }\right)$. The estimated $J_{\max }, V_{c \max }$ and a of siliques were considerably lower than the theoretical value calculated on the basis of a similar ratio between these parameters and chlorophyll concentration (i.e. $J_{\max } / \mathrm{Chl}, V_{\mathrm{cmax}} / \mathrm{Chl}$ and $\mathrm{a} / \mathrm{Chl}$ ) to leaves, of which the gaps between estimated- and theoretical-J $J_{\max }$ was the largest. In addition, the average ratio of $J_{\max }$ to $V_{c \max }$ was $16.1 \%$ lower than that of leaves, indicating that the weakened electron transport was insufficient to meet the requirements for carbon assimilation. Siliques contained larger but fewer stoma, tightly packed cross-section with larger cells and fewer intercellular air spaces, fewer and smaller chloroplasts and thin grana lamellae, which might be linked to the reduction in light capture and $\mathrm{CO}_{2}$ diffusion. K-deficiency significantly decreased leaf and silique $\mathrm{A}$ under the combination of down-regulated stomatal size and $g_{\mathrm{s}}$ chloroplast number, $\mathrm{a}, \mathrm{V}_{\mathrm{cmax}}$ and $J_{\max }$ while the $\mathrm{CO}_{2}$ diffusion distance between chloroplast and cell wall $\left(D_{\text {chl-cw }}\right)$ was enhanced. Siliques were more sensitive than leaves to $\mathrm{K}$-starvation, exhibiting smaller reductions in tissue $\mathrm{K}$ and parameters such as $g_{\mathrm{s},} V_{\mathrm{cmax}}, J_{\max }$ and $D_{\mathrm{chl}-\mathrm{cw}}$.

Conclusion: Siliques had substantially smaller $A$ than leaves, which was attributed to less efficient functioning of the photosynthetic apparatus, especially the integrated limitations of biochemical processes $\left(J_{\max }\right.$ and $\left.V_{c \operatorname{cmax}}\right)$ and a; however, siliques were slightly less sensitive to $\mathrm{K}$ deficiency.
\end{abstract}

Keywords: Brassica napus L., Leaf photosynthesis, Potassium deficiency, Silique photosynthesis, Structural properties

\footnotetext{
* Correspondence: rentao@mail.hzau.edu.cn

${ }^{1}$ Collge of Resources and Environment, Huazhong Agricultural University, Key

Laboratory of Arable Land Conservation (Middle and Lower Reaches of

Yangtze River) Ministry of Agriculture, Shizishan Street 1, Wuhan 430070,

People's Republic of China

Full list of author information is available at the end of the article
} 


\section{Background}

Carbon assimilation by chlorenchymal tissues contributes more than $90 \%$ of crop biomass [1]. Among chlorenchymas, leaves have long been considered as the principal organ responsible for photosynthetic activity in vascular plants, and the net $\mathrm{CO}_{2}$ assimilation of leaves has been studied extensively. However, mounting evidence indicates that non-foliar organs, such as reproductive structures, green stems, petioles, peduncles and roots, contain well-developed chloroplasts and contribute substantially to net carbon assimilation [2-5]. Among them, reproductive organs, such as siliques, panicles and cotton bolls, are usually green during their early development and contribute to the resource pool; however, they gradually become sink during maturation and senescence [6]. Therefore, fruit $\mathrm{CO}_{2}$ assimilation may particularly important for those plants to acquire extra $\mathrm{CO}_{2}$ and assimilates storage. Potassium (K), which is the most abundant univalent cation in plants, plays a crucial role in facilitating photosynthesis, construction of reproductive organs and crop yield. Previous studies have demonstrated the critical role of $\mathrm{K}$ in leaf photosynthesis [7-10]; however, this role remains to be confirmed in non-foliar organs.

Photosynthetically active organs can be divided into two groups according to their carbon gain. One group is characterized by net carbon assimilation using mainly atmospheric $\mathrm{CO}_{2}$, and another group performs effective utilization of respiratory $\mathrm{CO}_{2}$ [11]. Leaves, usually in the form of blades, absorb $\mathrm{CO}_{2}$ from the atmosphere mainly through the lower epidermal stomata, and deliver it across the mesophyll layers to the sites of carboxylation. $\mathrm{K}$ deficiency is known to limit leaf photosynthesis through diffusion resistance and biochemical obstacles [12]. K-starvation considerably decreases leaf stomatal conductance $\left(g_{\mathrm{s}}\right)$ and therefore, blocks the uptake of atmospheric $\mathrm{CO}_{2}$ leading to down-regulation of net photosynthetic rate $(A)[13,14]$. The non-foliar organs also contain stomatal pores, which, however, are quite different from that of leaf, generally with bigger stoma but lower density [11]. Their carbon demands are met either from the atmosphere or by reusing internally recycled $\mathrm{CO}_{2}$, or both. Despite progress in our understanding of the influence of $\mathrm{K}$ on leaf stomatal aperture, the effect of $\mathrm{K}$ on the non-foliar stomatal traits is remains to be elucidated. Mesophyll conductance $\left(g_{\mathrm{m}}\right)$ has long been considered a key factor, the influence of which is comparable to that of $g_{\mathrm{s}}$ in determining leaf $\mathrm{CO}_{2}$ diffusion [15]. Furthermore, $g_{\mathrm{m}}$ is down-regulated under K-deficiency as a consequence of the decreasing chloroplast surface area exposed to the airspace and increasing cytoplasmic resistance [10]. However, mesophyll conductance in non-leaf organ remains to be investigated. $\mathrm{CO}_{2}$ assimilation in chloroplast requires energy consumption that is dependent on Rubisco (ribulose 1,5-bisphosphate carboxylase) carboxylation. K-deficiency accelerates the degradation of leaf chloroplasts, resulting in chlorosis which reduces energy capture as well as the rate of electron transport and carboxylation $[8,13,14,16]$. Non-leaf organs contain well-developed chloroplasts; however, their chlorophyll content is only between $15 \%$ and $33 \%$ of that in the respective leaves $[11,17]$. This may affect the absorption and utilization of light energy, as well as the electron transport process and carboxylation rate. Additionally, swollen, or even ruptured chloroplasts, with poor contrast and obscure grana stacks are occasionally observed in K-starved leaves [18]. Since the integrity of the thylakoid membrane is essential for leaf $\mathrm{CO}_{2}$ assimilation, the down-regulation of $A$ under K-deficient conditions may be partly ascribed to the decrease in photochemical efficiency $[12,19]$. In contrast, little information is available on the structural variation of chloroplasts in non-foliar organs under K-starvation. Overall, the evidences described here suggests that there are differences in photosynthesis between leaves and non-foliar organs, with $\mathrm{K}$ levels presumably influencing organ photosynthetic capacity through structural and physiological regulation.

Winter oilseed rape (Brassica napus L.), an herbaceous annual plant, presents an obvious succession of photosynthetic organs during the process of growth (Additional file 1: Figure S1). Leaves, as the most important photosynthetic structure before the flowering stage, are responsible for generating and deploying carbohydrates in the construction of plant architecture and silique walls. At the onset of flowering, the decline in the leaf area index (LAI) is accelerated as a result of shading by the canopy, initially comprising yellow flowers and later, the siliques [20,21]. At the same time, silique area increases rapidly and, peaks at the start of ripening, with a maximum pod area index (PAI) equal to, or slightly less than, the LAI [21]. Specifically, leaves are the main photosynthetic structure before flowering stage, however, they are gradually senescent and separate from the plant beginning from the onset of flowering. Meanwhile, the siliques start to growth and occupy the hole canopy, and ultimately replace leaf as predominant carbon gain organs. The silique canopy intercepts approximately $80 \%$ of the incident radiation, and contributes to 80 to $95 \%$ of the total carbon gain during the pod filling stage [22]. Taken together, leaves and siliques are the two most important photosynthetic organs during the entire period of rapeseed growth. K-deficiency, in combination with a functional decline in leaf photosynthesis, causes rapeseed yield loss [23]. However, previous studies focusing on the influence of $\mathrm{K}$ in siliques, especially in $\mathrm{CO}_{2}$ assimilation, are rare. Therefore, in this study, Brassica napus L. was selected as a model plant to evaluate the differences between leaves and siliques and, their response to K-starvation. The aims of the current study were: (1) to compare the anatomical and 
photosynthetic differences between leaves and siliques by combining anatomical techniques with, gas exchange and chlorophyll fluorescence analyses; (2) to clarify the photosynthetic response of siliques under K-deficiency and the possible mechanism.

\section{Results}

\section{Morpho-physiological traits of leaves and siliques}

The biomass, area and chlorophyll concentration of individual leaves were significantly higher than the corresponding indexes of siliques, whereas siliques showed superiority in density and $\mathrm{K}$ concentration (Table 1 ). K-deficiency profoundly limited the growth of leaves and siliques, resulting in a reduction in most of the studied morpho-physiological traits (except that density was independent of $K$ nutrition). Specifically, biomass was the most affected index under K-deficiency among all the morphological traits, with a $17.9 \%$ and $15.4 \%$ decrease in leaves and siliques, respectively (Table 1 and Fig. 1). In comparison with $+\mathrm{K}$ treatment, the chlorophyll concentration of leaves and siliques decreased by approximately $35.0 \%$, with a more marked decline in $K$ concentration in leaves compared with that in silique (Table 1 and Fig. 1).

\section{Response of photosynthesis to irradiation and $\mathrm{CO}_{2}$ concentration}

Under light saturation conditions, the net photosynthetic rate $(A)$ of leaves under the $-\mathrm{K}$ and $+\mathrm{K}$ treatments were 2.6 and 2.9 times the rates of siliques, respectively (Table 2). Leaf stomatal conductance $\left(g_{\mathrm{s}}\right)$ was also considerably higher than that of siliques; however, intercellular $\mathrm{CO}_{2}$ concentration $\left(C_{\mathrm{i}}\right)$ was slightly lower in leaves. K-deficiency significantly down-regulated $A$ and $g_{\mathrm{s}}$, yet had completely opposite effects on $C_{\mathrm{i}}$ between leaves and siliques. In terms of $A$ and $g_{s}$, leaves were more sensitive than siliques to $\mathrm{K}$ deficiency (Fig. 1).

As irradiations and $\mathrm{CO}_{2}$ concentrations increased, $A$ increased rapidly, peaked and finally stabilized (Fig. 2). It could be concluded from the simulation parameters of the light- and $\mathrm{CO}_{2}$-response curves that the apparent quantum yield $(\alpha)$ and carboxylation rate $(\mathrm{CE})$ were enhanced in leaves compared with the values in siliques (Table 2). The ratio between $\alpha$ and chlorophyll concentration $(\alpha / \mathrm{Chl})$ was higher in leaves versus that of siliques; however, there was no difference in the ratio of $\mathrm{CE}$ to chlorophyll concentration (CE/Chl) between leaves and siliques. K-deficiency significantly decreased the initial rate of increase and maximum values of $A, \alpha /$ $\mathrm{Chl}$ and $\mathrm{CE} / \mathrm{Chl}$. The response of leaves to K-deficiency was slightly higher than that of siliques (Fig. 1).

\section{Mapping chlorophyll fluorescence}

The imaging-PAM analysis showed weaker minimum fluorescence $\left(F_{\mathrm{o}}\right)$ and quantum yield of regulated energy dissipation $(\mathrm{Y}(\mathrm{NPQ}))$ in siliques compared with leaves; however, the maximum quantum yield of PSII $\left(F_{\mathrm{v}} / F_{\mathrm{m}}\right)$ and actual photochemical efficiency of PSII (Y(II)) was higher (Fig. 3). The average $F_{\mathrm{o}}$ values of the organs evaluated were significantly higher under K-deficiency than those in the $+\mathrm{K}$ treatment groups. Compared with the $-\mathrm{K}$ treatment, $+\mathrm{K}$ treatment improved $\mathrm{Y}$ (II) by $14.4 \%$ and $18.3 \%$ in leaves and siliques, respectively; nevertheless, for $\mathrm{Y}(\mathrm{NPQ})$, decreases of $37.1 \%$ and $25.2 \%$, respectively, were observed. Furthermore, $\mathrm{K}$ supply improved $F_{\mathrm{v}} / F_{\mathrm{m}}$ of leaves and siliques. Obvious heterogeneities were observed in the images, especially the maps captured from leaves in the $-\mathrm{K}$ treatment, with enhanced $\mathrm{Y}(\mathrm{NPQ})$ and reduced $\mathrm{Y}(\mathrm{II})$.

\section{Anatomical traits of leaves and siliques}

The leaf and pericarp structures showed marked differences. Leaves consisted of two epidermal layers (upper and lower), palisade and spongy layers (Fig. 4a, b), while the pericarp classified into three functional layers-the exocarp, mesocarp and endocarp (Fig. 4c, d). The leaf epidermis and exocarp were formed by single-celled epidermal layers, while the palisade, spongy layers (Fig. 4a, b) and mesocarp were composed of layers of chlorenchyma cells, and the endocarp consisted of large thinwalled cells and an inner layer with small, tightly packed cells (Fig. 4c, d). There was a large intercellular air space in the spongy layers of leaves, but not in the mesocarp layer of the pericarp. Additionally, K supply significantly

Table 1 Effects of K supply on morphological and physiological traits of leaves and siliques

\begin{tabular}{lllllllll}
\hline Organs & Treatment & Biomass $(\mathrm{g})$ & Area $\left(\mathrm{cm}^{2}\right)$ & $M_{\mathrm{A}}\left(\mathrm{g} \mathrm{m}^{-2}\right)$ & Thickness $(\mu \mathrm{m})$ & Density $\left(\mathrm{g} \mathrm{cm}^{-3}\right)$ & $\left.\mathrm{Chl}_{(\mathrm{g} \mathrm{m}}{ }^{-2}\right)$ & $\mathrm{K}$ concentration $(\%)$ \\
\hline Leaf & $-\mathrm{K}$ & $2.48 \pm 0.17 \mathrm{~b}$ & $336.8 \pm 28.2 \mathrm{~b}$ & $73.9 \pm 1.8 \mathrm{a}$ & $313.9 \pm 4.3 \mathrm{~b}$ & $0.235 \pm 0.006 \mathrm{a}$ & $0.42 \pm 0.06 \mathrm{~b}$ & $0.89 \pm 0.06 \mathrm{~b}$ \\
& $+\mathrm{K}$ & $3.02 \pm 0.07 \mathrm{a}$ & $401.9 \pm 14.7 \mathrm{a}$ & $77.1 \pm 2.3 \mathrm{a}$ & $327.6 \pm 2.8 \mathrm{a}$ & $0.235 \pm 0.007 \mathrm{a}$ & $0.64 \pm 0.06 \mathrm{a}$ & $2.12 \pm 0.05 \mathrm{a}$ \\
\multirow{2}{*}{ Silique } & $-\mathrm{K}$ & $0.11 \pm 0.00 \mathrm{~b}^{*}$ & $6.6 \pm 0.1 \mathrm{~b}^{*}$ & $73.1 \pm 3.8 \mathrm{~b}$ & $304.8 \pm 5.2 \mathrm{~b}^{*}$ & $0.240 \pm 0.012 \mathrm{a}$ & $0.20 \pm 0.01 \mathrm{~b}^{*}$ & $2.05 \pm 0.06 \mathrm{~b}^{*}$ \\
& $+\mathrm{K}$ & $0.13 \pm 0.01 \mathrm{a}^{*}$ & $7.4 \pm 0.2 \mathrm{a}^{*}$ & $85.9 \pm 2.0 \mathrm{a}^{*}$ & $333.6 \pm 4.8 \mathrm{a}$ & $0.257 \pm 0.006 \mathrm{a}^{*}$ & $0.32 \pm 0.02 \mathrm{a}^{*}$ & $3.27 \pm 0.03 \mathrm{a}^{*}$ \\
\hline
\end{tabular}

$M_{\mathrm{A}}$ leaf (silique) mass per area; Chl, chlorophyll content. Data represent mean \pm standard error (SE) of four replicates for biomass, area, $M_{\mathrm{A}}$, density, Chl and $\mathrm{K}$ concentration, and at least 16 replicates for leaf thickness

Different letters indicate statistically significant differences $(P<0.05)$ between the $-\mathrm{K}$ and $+\mathrm{K}$ treatments

*Indicates statistically significant differences $(P<0.05)$ between the two organs under the same treatment conditions 


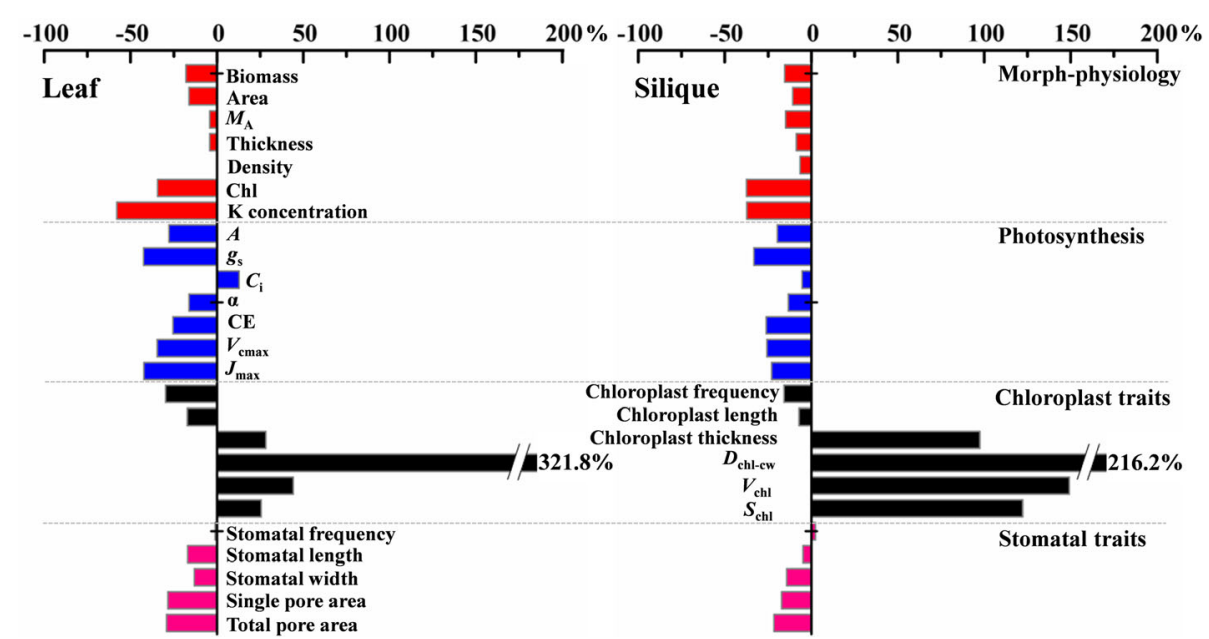

Fig. 1 Changes in morph-physiological (red bars), photosynthetic (blue bars), stomatal (black bars) and chloroplastic traits (pink bars) of leaves and siliques in response to K-deficiency. The response ratio was calculated as the relative variation of each parameters under K-deficiency using the $+\mathrm{K}$ treatment as a control. Value bars facing the left and right indicate decreases and increases in traits compared to the values under $+\mathrm{K}$ treatment, respectively. $M_{\mathrm{A}}$, leaf (silique) mass per area; $C h l$, chlorophyll content; $A$, net photosynthetic rate; $g_{\mathrm{s}}$ stomatal conductance; $C_{i}$, substomatal $\mathrm{CO}_{2}$ concentration; $\mathrm{a}$, apparent quantum yield; $C E$, carboxylation efficiency; $V_{c \text { max }}$ the maximum rate of RuBP carboxylation; $J_{\max }$ the maximum rate of electron transport. $D_{c h l-c w}$ the distance between chloroplast and cell wall; $V_{\text {chl, }}$ chloroplast volume; $S_{\text {chl, }}$ chloroplast surface area

improved the thickness of leaves and siliques (Table 1 and Fig. 4a-d).

Stomatas were distributed in the leaf epidermis and silique exocarp, and the average number of stomata in the lower leaf epidermis was approximately 5 -fold higher than that of the silique outer epidermis; however, the silique stomata size, i.e., stomatal length, width and single pore area, were much larger (Table 3 and Fig. 4e-h). The total pore area, which is the product of stomatal frequency and single pore area, was considerably increased in leaves. $K$ deficiency decreased stomatal size, but had no influence on stomatal frequency.

Compared with siliques, leaf mesophyll cells contained more chloroplasts, which were greater in length and thickness, as well as enlarged chloroplast surface area and volume (Table 4 and Fig. 4m-p).
Occasional starch granules were observed in the leaf chloroplasts (Fig. 4i, j); however, they were ubiquitously present in the chloroplasts of silique cells (Fig. 4k, l). In addition, the grana lamellae were thicker in leaf chloroplasts. The chloroplast frequency per cell decreased in the $-K$ treatment, nevertheless, the chloroplast size and the distance between the chloroplast and cell wall were significantly enhanced. In the presence of a sufficient $\mathrm{K}$ supply, chloroplasts were regular ellipsoidal in shapes, the granum thylakoid was well-developed and the grana lamellae structures were clear and integral (Fig. 4n, p). However, in K-starved leaves, the chloroplast envelope was swollen and even ruptured in some cases, with a circular profile, and the granum thylakoid was irregularly arranged (Fig. 4m). In silique chloroplasts, K-deficiency caused marked

Table 2 Effects of $\mathrm{K}$ supply on photosynthetic parameters of light- and $\mathrm{CO}_{2}$-response curves

\begin{tabular}{|c|c|c|c|c|c|c|c|c|}
\hline Organs & Treatment & $A\left(\mu \mathrm{mol} \mathrm{m}{ }^{-2} \mathrm{~s}^{-1}\right)$ & $g_{s}\left(\mathrm{~mol} \mathrm{~m}{ }^{-2} s^{-1}\right)$ & $C_{i}\left(\mu \mathrm{mol} \mathrm{mol}{ }^{-1}\right)$ & a & $\mathrm{a} / \mathrm{Chl}\left(\mathrm{m}^{-2} / \mathrm{g}\right)$ & CE & CE/Chl $\left(\mathrm{m}^{-2} / \mathrm{g}\right)$ \\
\hline \multirow[t]{2}{*}{ Leaf } & $-K$ & $16.8 \pm 1.7 b^{1}$ & $0.199 \pm 0.009 b$ & $264 \pm 7 a$ & $0.0463 \pm 0.0023 b$ & $0.1103 \pm 0.0054 a$ & $0.0604 \pm 0.0012 b$ & $\overline{0.1438 \pm 0.0027 a}$ \\
\hline & $+K$ & $23.3 \pm 1.1 \mathrm{a}$ & $0.346 \pm 0.012 a$ & $234 \pm 6 b$ & $0.0552 \pm 0.0022 a$ & $0.0863 \pm 0.0034 b$ & $0.0811 \pm 0.0008 a$ & $0.1267 \pm 0.0022 b$ \\
\hline \multirow[t]{2}{*}{ Silique } & $-K$ & $6.5 \pm 0.1 b^{*}$ & $0.108 \pm 0.009 b^{*}$ & $281 \pm 4 a$ & $0.0184 \pm 0.0004 b^{*}$ & $0.0921 \pm 0.0018 a^{*}$ & $0.0304 \pm 0.0003 b^{*}$ & $0.1521 \pm 0.0028 a$ \\
\hline & $+K$ & $8.1 \pm 0.3 a^{* 2}$ & $0.162 \pm 0.004 a^{*}$ & $297 \pm 4 a^{*}$ & $0.0212 \pm 0.0003 a^{*}$ & $0.0663 \pm 0.0009 b^{*}$ & $0.0411 \pm 0.0002 a^{*}$ & $0.1285 \pm 0.0008 b$ \\
\hline
\end{tabular}

$A$, net photosynthetic rate; $g_{\mathrm{s}}$, stomatal conductance; $\mathrm{C}_{\mathrm{i}}$, substomatal $\mathrm{CO}_{2}$ concentration; $\mathrm{a}$, apparent quantum yield; $\mathrm{a} / \mathrm{Chl}$, apparent quantum yield per chlorophyll concentration; $\mathrm{CE}$, carboxylation efficiency; $\mathrm{CE} / \mathrm{Chl}$, carboxylation efficiency per chlorophyll concentration

Data represent mean \pm standard error (SE) of four replicates for parameters under light saturation conditions and three replicates for simulation parameters of light- and $\mathrm{CO}_{2}$-response curves

Different letters indicate statistically significant differences $(P<0.05)$ between the $-\mathrm{K}$ and $+\mathrm{K}$ treatments

*Indicates statistically significant differences $(P<0.05)$ between the two organs under the same treatment conditions 


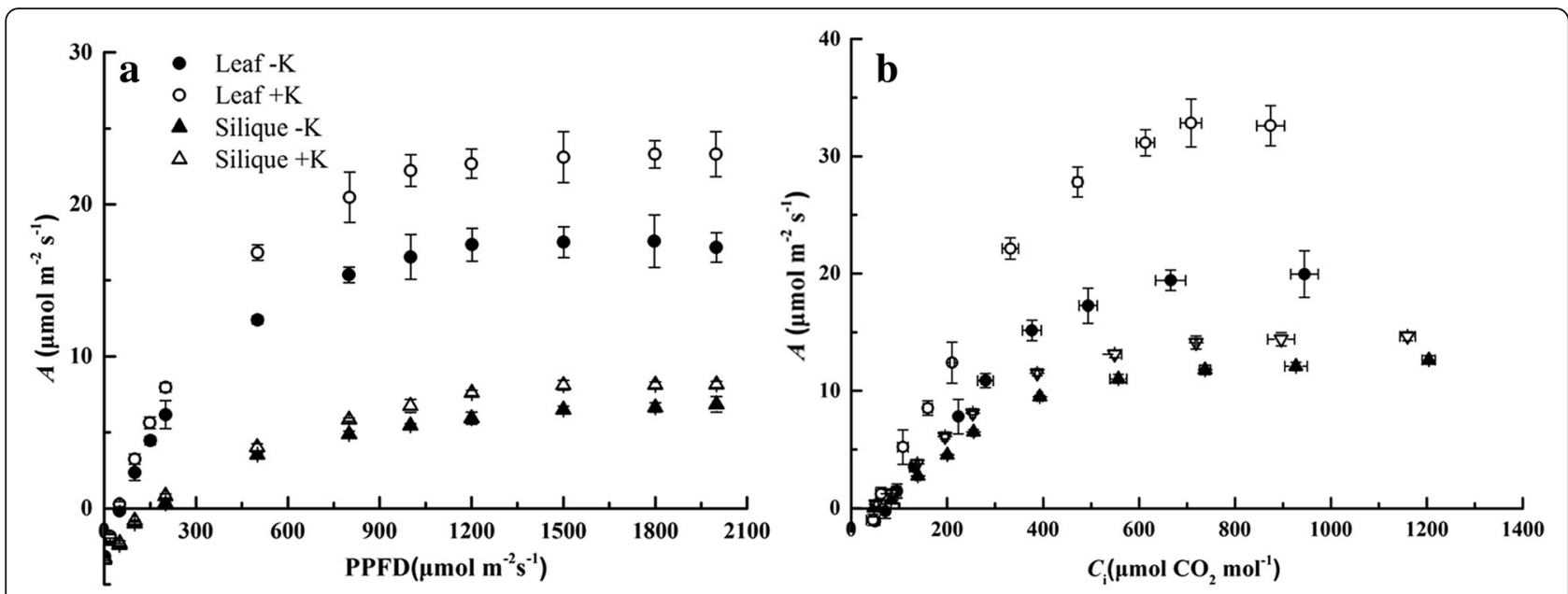

Fig. 2 Light $(\mathbf{a})$ and $\mathrm{CO}_{2}(\mathbf{b})$ response curves showing the net photosynthetic rate $(A)$ in leaves and siliques under K-deficiency $(-K)$ and sufficient $\mathrm{K}$ supply (+K) treatments. Values represent mean \pm standard error $(\mathrm{SE})$ of three replicates

starch accumulation, which ultimately resulted in a 2.2 -fold increase in volume compared with that observed in the $+\mathrm{K}$ treatment (Table 4 and Fig. 4o). The average distances between the chloroplast and cell wall $\left(D_{\text {chl-cw }}\right)$ of leaves and siliques were markedly enhanced in the $-\mathrm{K}$ treatment, with a greater distance between chloroplasts and the cell wall in leaves (Table 4 and Fig. 1).

\section{Discussion}

The enhanced gap in the average $A$ between leaves and siliques is associated with integrated limitations of biochemical processes $\left(J_{\max }\right.$ and $\left.V_{c \max }\right)$ and apparent quantum yield (a)

The silique wall has been asserted as a modified leaf [6, 17], optimized for plant light harvesting and yield performance. The average net photosynthetic rate $(A)$ of

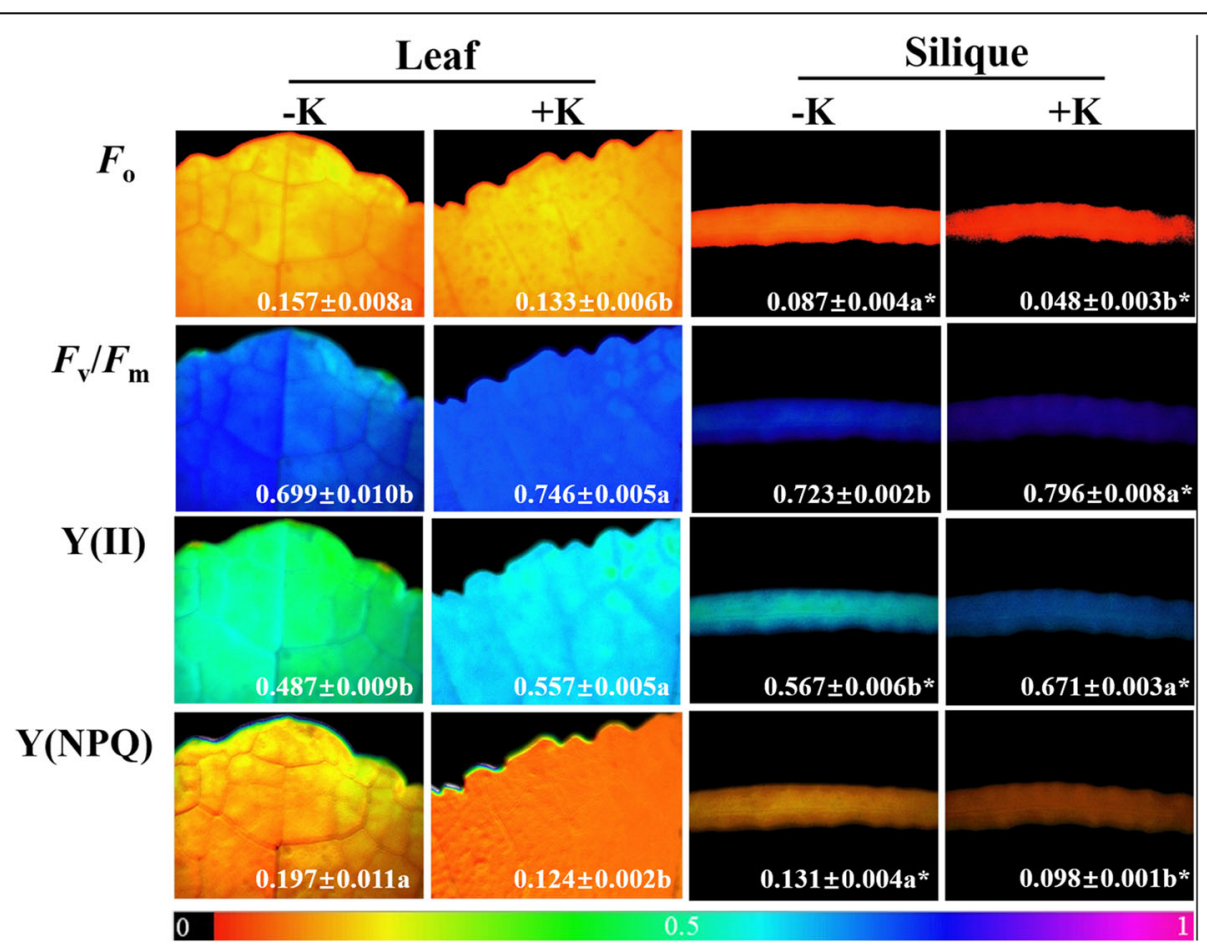

Fig. 3 Images obtained by imaging-PAM analysis of leaves and siliques in K-deficiency $(-K)$ and sufficient $K$ supply $(+K)$ treatments. Values represent mean \pm standard error $(\mathrm{SE})$ of three replicates indicate the intensity of each parameter. $F_{\mathrm{o}}$ : minimum fluorescence; $F_{\mathrm{v}} / F_{\mathrm{m}}$ : maximum quantum yield of PSII; Y(II), actual photochemical efficiency of PSII; $Y(N P Q)$, quantum yield of regulated energy dissipation 


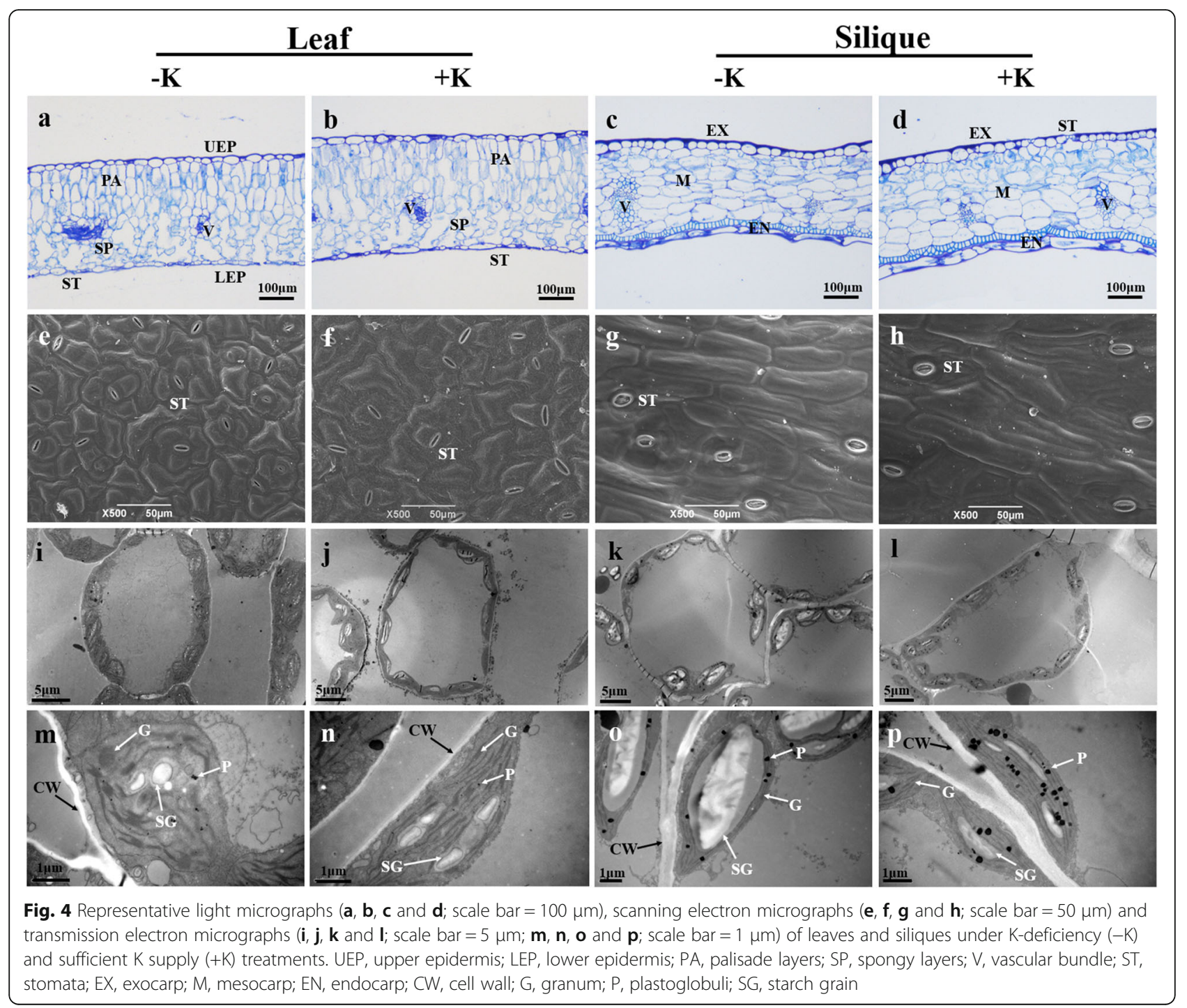

silique wall was 6.5 to $8.1 \mu \mathrm{mol} \mathrm{m} \mathrm{m}^{-2} \mathrm{~s}^{-1}$ depending on different $\mathrm{K}$ treatments, with the range of values commonly reported [22]. Silique $A$ was only approximately $35.0 \%$ that of leaf, analogous to many non-foliar organs for which $A$ is between 20 and $80 \%$ of that in leaves [4, 11]. The rate of photosynthesis is dependent on energy and reductant availability and the biochemical synthesis of carbohydrates with $\mathrm{CO}_{2}$ as a substrate. In the present study, these factors were evaluated based on the combination of light- and $\mathrm{CO}_{2}$-response curves and chlorophyll fluorescence. Leaf $A$ was much higher than that of siliques, regardless of the gradients of light intensity or $\mathrm{CO}_{2}$ concentration (Fig. 2). Similar relationships have been reported for the comparison of leaf- and non-leaf photosynthesis in Zantedeschia aethiopica [24] and Helleborus viridis [4]. The two chlorophyll-related

Table 3 Effects of K-deficiency on stomatal characteristics of leaves and siliques

\begin{tabular}{lllllll}
\hline Organs & Treatment & Frequency $\left(\mathrm{no} . \mathrm{mm}^{-2}\right)$ & Length $(\mu \mathrm{m})$ & Width $(\mu \mathrm{m})$ & Single pore area $\left(\mu \mathrm{m}^{2}\right)$ & ${\text { Total pore area }\left(\mu \mathrm{m}^{2}\right)}^{2}$ \\
\hline Leaf & $-\mathrm{K}$ & $348.5 \pm 7.5 \mathrm{a}^{1}$ & $8.51 \pm 0.21 \mathrm{~b}$ & $3.10 \pm 0.12 \mathrm{~b}$ & $21.19 \pm 1.12 \mathrm{~b}$ & $7.39 \pm 0.44 \mathrm{~b}$ \\
& $+\mathrm{K}$ & $352.6 \pm 10.8 \mathrm{a}$ & $10.26 \pm 0.26 \mathrm{a}$ & $3.57 \pm 0.12 \mathrm{a}$ & $29.58 \pm 0.71 \mathrm{a}$ & $10.43 \pm 0.57 \mathrm{a}$ \\
Silique & $-\mathrm{K}$ & $72.79 \pm 4.76 \mathrm{a}^{* 2}$ & $13.39 \pm 0.30 \mathrm{~b}^{*}$ & $6.40 \pm 0.25 \mathrm{~b}^{*}$ & $65.15 \pm 3.43 \mathrm{~b}^{*}$ & $4.39 \pm 0.19 \mathrm{~b}^{*}$ \\
& $+\mathrm{K}$ & $71.07 \pm 2.21 \mathrm{a}^{*}$ & $14.05 \pm 0.20 \mathrm{a}^{*}$ & $7.47 \pm 0.24 \mathrm{a}^{*}$ & $78.73 \pm 2.43 \mathrm{a}^{*}$ & $5.60 \pm 0.17 \mathrm{a}^{*}$ \\
\hline
\end{tabular}

Data represent mean \pm standard error (SE) of at least 20 replicates for stomatal frequency and 50 replicates for other traits

Different letters indicate statistically significant differences $(P<0.05)$ between the $-\mathrm{K}$ and $+\mathrm{K}$ treatments

*Indicates statistically significant differences $(P<0.05)$ between two organs under the same treatment conditions 
Table 4 Effects of K-deficiency on chloroplast ultrastructure of leaves and siliques

\begin{tabular}{llllllll}
\hline Organs & Treatment & Frequency $($ no. per cell) & Length $(\mu \mathrm{m})$ & Thickness $(\mu \mathrm{m})$ & $D_{\text {chl-cw }}(\mu \mathrm{m})$ & $V_{\text {chl }}\left(\mu \mathrm{m}^{3}\right)$ & $S_{\text {chl }}\left(\mu \mathrm{m}^{2}\right)$ \\
\hline Leaf & $-\mathrm{K}$ & $10.9 \pm 0.9 \mathrm{a}^{1}$ & $5.77 \pm 0.20 \mathrm{~b}$ & $3.13 \pm 0.13 \mathrm{a}$ & $0.426 \pm 0.057 \mathrm{a}$ & $32.03 \pm 2.69 \mathrm{a}$ & $47.18 \pm 2.77 \mathrm{a}$ \\
& $+\mathrm{K}$ & $15.5 \pm 1.2 \mathrm{a}$ & $6.97 \pm 0.18 \mathrm{a}$ & $2.44 \pm 0.08 \mathrm{~b}$ & $0.101 \pm 0.010 \mathrm{~b}$ & $22.21 \pm 1.44 \mathrm{~b}$ & $37.57 \pm 1.60 \mathrm{~b}$ \\
Silique & $-\mathrm{K}$ & $11.2 \pm 0.7 \mathrm{~b}$ & $4.96 \pm 0.80 \mathrm{a}^{*}$ & $3.06 \pm 0.89 \mathrm{a}$ & $0.313 \pm 0.021 \mathrm{a}^{*}$ & $26.48 \pm 3.43 \mathrm{a}^{*}$ & $41.58 \pm 3.50 \mathrm{a}^{*}$ \\
& $+\mathrm{K}$ & $13.3 \pm 1.2 \mathrm{a}^{* 2}$ & $5.34 \pm 1.46 \mathrm{a}^{*}$ & $1.55 \pm 0.62 \mathrm{~b}^{*}$ & $0.099 \pm 0.005 \mathrm{~b}$ & $10.63 \pm 2.32 \mathrm{~b}^{*}$ & $18.71 \pm 2.92 \mathrm{~b}^{*}$ \\
\hline
\end{tabular}

Data represent mean \pm standard error $(\mathrm{SE})$ of at least 30 replicates. $D_{\mathrm{chl}-\mathrm{cw}}$, the distance between the chloroplast and cell wall; $V_{\mathrm{chl}}$, chloroplast volume; $S_{\mathrm{chl}}$, chloroplast surface area

Different letters indicate statistically significant differences $(P<0.05)$ between the $-\mathrm{K}$ and $+\mathrm{K}$ treatments

*Indicates statistically significant differences $(P<0.05)$ between the two organs under the same treatment conditions

parameters, apparent quantum yield $(\alpha)$ and carboxylation efficiency $(\mathrm{CE})$, which can be modeled from the initial slope of the linear part of light- and $\mathrm{CO}_{2}$-response curves, played important roles in regulating $A$ by influencing light harvesting and ribulose 1,5-bisphosphate (RuBP) carboxylation. Leaves showed discernible advantages in $\alpha$ and CE; however, when based on their own chlorophyll concentration, leaf $\alpha / \mathrm{Chl}$ was slightly higher than that of siliques, while the $\mathrm{CE} / \mathrm{Chl}$ ratios of the two organs were similar (Table 2). If silique $\alpha / \mathrm{Chl}$ and $\mathrm{CE} /$ Chl were assumed to be the same as those of leaves, the CE values estimated from the $A-C_{\mathrm{i}}$ curves were close to the modeled values (Fig. 5a). Nevertheless, the estimated $\alpha$ values were $16.6 \%$ and $23.2 \%$ lower than the theoretical values in the $-\mathrm{K}$ and $+\mathrm{K}$ treatment, respectively (Fig. 5a and Additional file 2: Table S1). For this reason, $\alpha$ was deemed to be more important than CE in determining the difference in $A$ between leaves and siliques. However, the opposite result was reported for Zantedeschia aethiopica in that the CE of petioles decreased by $65.8 \%$ in compared with the theoretical value under the assumption of consistent $\mathrm{CE} / \mathrm{Chl}$ between leaves and petioles; however, the variation in $\alpha$ was less pronounced [4].

The most common purpose of $A-C_{\mathrm{i}}$ curves is to assess in vivo maximum rates of electron transport $\left(J_{\max }\right)$ and the maximum rate of RuBP carboxylation $\left(V_{\text {cmax }}\right)$, as well as the transformation of RuBP carboxylation and regeneration limitations, which can be altered by the balance of $J_{\max }$ and $V_{\text {cmax }}$ and the intercellular $\mathrm{CO}_{2}$ concentration $\left(C_{\mathrm{i}}\right)[25,26]$. In the current study, the $V_{\text {cmax }}$ and $J_{\max }$ values of leaves were 2.63-2.98 and 2.87-3.83 times that of siliques, respectively, leading to a lower $J_{\max } / V_{\text {cmax }}$ in siliques (Fig. 6). The down-regulated $J_{\max } / V_{\text {cmax }}$ in siliques may be correlated with a greater limitation by RuBP regeneration than by carboxylation, which implies that the weakened electron transport could not meet the requirements for carbon assimilation [26]. The average intercellular $\mathrm{CO}_{2}$ concentration at which the transition from Rubisco to RuBP regeneration $\left(C_{\text {transition }}\right)$ of leaves was $505.1 \mu \mathrm{mol} \mathrm{CO} \mathrm{mol}^{-1}$, which was $51.0 \mu \mathrm{mol} \mathrm{CO} \mathrm{Col}^{-1}$ higher than that of siliques
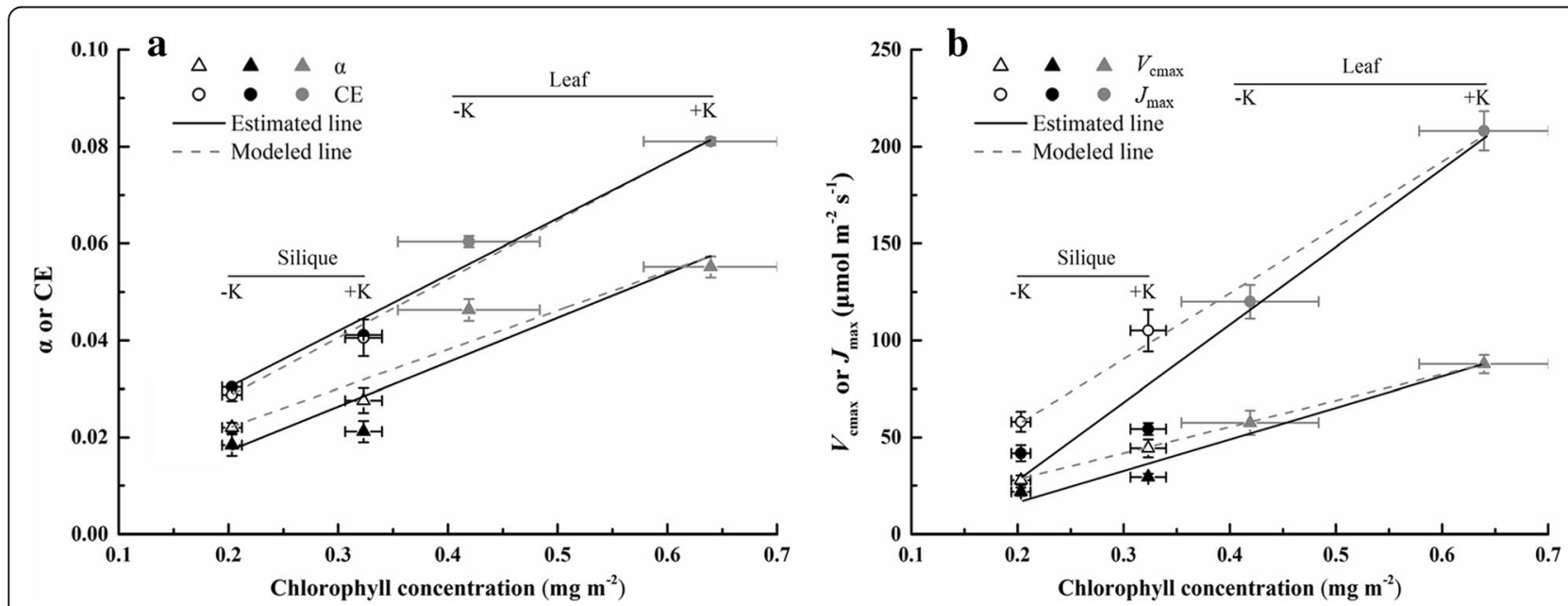

Fig. 5 The relationship between estimated and modeled (a) apparent quantum yield (a) and carboxylation efficiency (CE), (b) the maximum rate of electron transport $\left(U_{\max }\right)$ and the maximum rate of RuBP carboxylation $\left(V_{c \max }\right)$ of siliques with chlorophyll concentrations. The dashed gray lines in (a) represent the modeled a or CE, assuming that the ratio between a or CE and chlorophyll concentration of siliques was the same as the values for leaves, and indicate the modeled $J_{\max }$ or $V_{\text {cmax }}$ under the assumption that the ratio between $J_{\max }$ or $V_{\text {cmax }}$ and chlorophyll concentration of siliques was the same as the values for leaves in (b). The solid black lines denote the values estimated from the light and $\mathrm{CO}_{2}$ response curves. Values represent mean \pm standard error (SE) of three replicates 

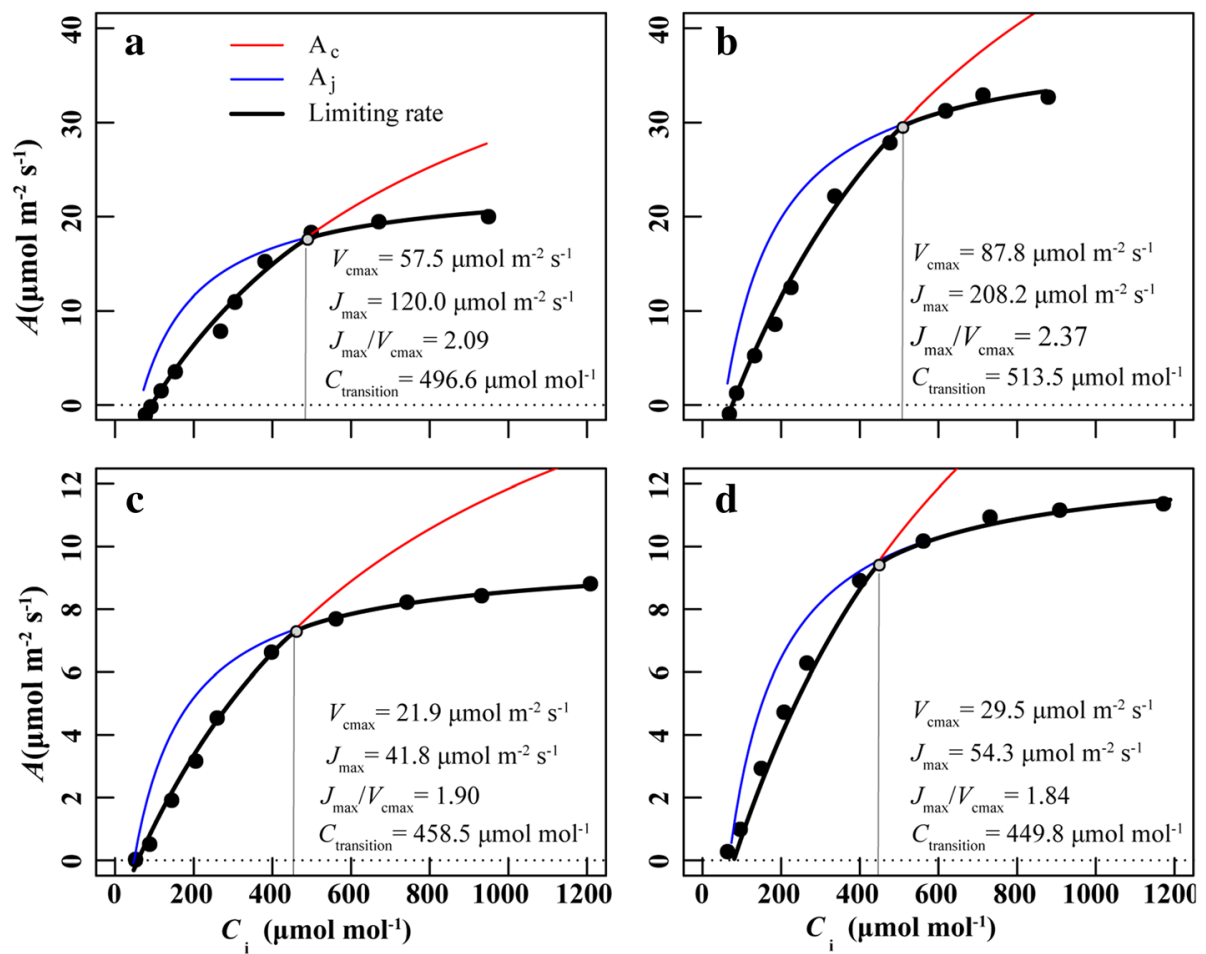

Fig. 6 Illustration showing the shift in the limiting step of $\mathrm{CO}_{2}$ assimilation. $\mathbf{a}$ and $\mathbf{b}$ are limitations of leaves under $\mathrm{K}$-deficiency $(-\mathrm{K})$ and sufficient $\mathrm{K}$ supply $(+\mathrm{K})$ treatments, while $\mathbf{c}$ and $\mathbf{d}$ are corresponding traits of siliques. $\mathrm{CO}_{2}$ assimilation rate limited by RuBP carboxylation ( $A_{c}$ : red line), RuBP regeneration ( $A_{r}$ : blue line), the maximum rate of RuBP carboxylation $\left(V_{c \max }\right)$, the maximum rate of electron transport $\left(J_{\max }\right)$ and the intercellular $\mathrm{CO}_{2}$ concentration at which the transition from Rubisco to RuBP regeneration limitation occurs $\left(C_{\text {transition }}\right)$ were modeled and calculated using the Farquhar, von Caemmerer and Berry (FVCB) photosynthesis model with R plantecophys package

(Fig. 6). This provided support for our inference, showing that siliques were more restricted in terms of $J_{\max }$ rather than $V_{\text {cmax }}$. Further evidence was provided by our investigation of the differences between the estimated and modeled values on the basis of constant $J_{\max } / \mathrm{Chl}$ and $V_{\text {cmax }} / \mathrm{Chl}$ in leaves and siliques. The estimated $-J_{\max }$ of siliques were $28.0 \%$ and $48.3 \%$ lower than modeled$J_{\max }$ in the $-\mathrm{K}$ and $+\mathrm{K}$ treatment, respectively, while the gap between estimated- $V_{\text {cmax }}$ and modeled- $V_{\text {cmax }}$ was much smaller (Fig. 5b and Additional file 2: Table S1). It can also be speculated from Fig. 5 that the contributions of $J_{\max }$ and $V_{\text {cmax }}$ to the decreased rate of silique photosynthesis were higher than that of $\alpha$.

Several lines of supporting evidence were provided by comparisons of cell arrangement and chloroplast ultrastructure of the two organs in cross-section. Silique walls had broader cells, however, the cells were fewer in in number (Fig. 4c, d), resulting in a lessened cell surface area per unit of mesophyll volume, and decreasing the light harvesting efficiency of the tissue [27]. In addition, the lack of spongy tissue and larger intercellular airspace had an adverse effect on light scattering [27, 28], thus further decreasing light absorption by siliques. As for the ultrastructure, silique wall chloroplasts were much smaller in size, with a decrease in the number of layers per granum (Fig. 4o-p). This organization of grana has been approved to influence the formation of arrays of PSII-LHCII supercomplexes, ultimately affecting light harvesting [29], and also influencing light-to-charge conversion and electron transport [30]. Nevertheless, the case of discrepancy between comparable actual photochemical efficiency of PSII (Y(II)), maximum quantum yield of PSII $\left(F_{\mathrm{v}} / F_{\mathrm{m}}\right)$ and in vivo chlorophyll fluorescence of photosystem II-based electron transport rate (ETR) (Additional file 3: Figure S2), with considerably different $A$ and $J_{\max }$ in the two organs is intriguing. This phenomenon may be accounted for the distribution of electrons to an alternative electron sink such as photorespiration, which may ultimately reduce the pool of electrons available for carboxylation [4]. Another noteworthy fact was that electrons were also consumed by the refixation of internal-cavity respiratory $\mathrm{CO}_{2}(0.5$ to $2.5 \% \mathrm{v} / \mathrm{v}$ in the silique cavity); however, it was not possible to evaluated this by gas exchange or chlorophyll fluorescence [11, 31, 32], as has been proposed for tomato and mango fruit $[11,33]$. Nevertheless, it is not known whether these two possibilities exist in silique or which is the main restraint for electrons distribution to 
$\mathrm{CO}_{2}$ assimilation. Additionally, the variation of substrate $\mathrm{CO}_{2}$ in chloroplasts will lead to changes in $A$ and the pools of Calvin cycle intermediates, which can affect the activity of Rubisco and the capacity for RuBP regeneration [34]. Even with extremely declined $g_{\mathrm{s}}$, the intercellular $\mathrm{CO}_{2}$ concentration $\left(C_{\mathrm{i}}\right)$ of siliques was slightly enhanced, possibly caused by restricted $\mathrm{CO}_{2}$ diffusion in mesophyll layers or in efficient use of $\mathrm{CO}_{2}$. To date, there is no effective method to evaluate the resistance of $\mathrm{CO}_{2}$ diffusion through cross-sections of non-leaf organs, especially those with unevenly distributed chloroplasts [35]. Since mesophyll conductance $\left(g_{\mathrm{m}}\right)$ is highly dependent on the anatomical traits of mesophyll cells and chloroplasts [36], the micro- or ultra-structures may offer several lines of evidence. Compared with leaves, silique walls had less intercellular airspace and fewer and smaller chloroplasts, which might ultimately decrease gas-phase conductance and the chloroplast area exposed to airspace $\left(S_{\mathrm{c}} / S\right)$ and, in turn, down-regulated $g_{\mathrm{m}}$.

\section{Effects of potassium on leaf and silique photosynthesis}

In the present study, notable inhibition of the growth of leaves and siliques was observed under K-depletion. Both organs exhibited the same morphological response to K-deficiency, displaying a reduction in photosynthetic area, leaf (silique) mass per area $\left(M_{\mathrm{A}}\right)$ and thickness, which is largely in accordance with previous observations [10, 37]. However, leaf growth was more affected by K-deficiency, with an extremely reduced $\mathrm{K}$ status. In higher plants, $\mathrm{K}$ is particularly concentrated in growing and reproductive organs, reflecting its ease of transportation [38]. Siliques, which are propagative organs, contain a naturally high $K$ concentration, which is approximately 2 -folder greater than that of leaves. Based on studies of the relationship between the biochemical properties of organs (e.g. photosynthesis), it can be hypothesized that the critical $\mathrm{K}$ concentration of siliques is higher than that of leaves (1.07\%) [16].

In comparison with siliques, leaf photosynthesis was more restricted by $\mathrm{K}$ deficiency, which to a certain extent, was attributed to a sensitive stoma, a greatly increased $\mathrm{CO}_{2}$ diffusion distance between the chloroplast and cell wall $\left(D_{\text {chl-cw }}\right)$, and a down-regulation of $J_{\max }$ and $V_{\text {cmax }}$ (Table 2 and Fig. 1). In accordance with previous reports, K-deficiency decreased stomatal length, width and pore area in both organs $[14,16]$, however, had no influence on stomatal density. The stomatal function, often referred to stomatal conductance to $\mathrm{CO}_{2}\left(g_{\text {sc }}\right)$, was down-regulated under $\mathrm{K}$-starved conditions in the present study, which is consistent with observations in cotton [39], hickory [13], eucalyptus [14] and sunflower [12]. Therefore, the resistance to $\mathrm{CO}_{2}$ diffusion from the atmosphere to the leaf interior was extremely enhanced under conditions of K-deprivation, and this resistance was more pronounced in siliques. However, the higher $C_{\mathrm{i}}$ values in K-starved leaves versus that of $+\mathrm{K}$ treatment indicated that the major influence of $\mathrm{K}$ on leaf photosynthesis under current condition may be attributed to lower $g_{\mathrm{m}}$ and the capacity of $\mathrm{CO}_{2}$-fixiation (biochemical activities), rather than stomatal limitations [13]. The $C_{\mathrm{i}}$ value of silique was independent of $\mathrm{K}$ nutrition, which ultimately led to an uncertain causality between main limiting factors and down-regulated $A$.

Leaf $g_{\mathrm{m}}$ plays an important role in determining $\mathrm{CO}_{2}$ acquisition of chlorenchymas [36, 40]. Our previous study indicated that K-deficiency reduced leaf $g_{\mathrm{m}}$ by decreasing intercellular air spaces, $S_{\mathrm{c}} / S$ and enlarging the resistance of the cytoplasm (i.e. $D_{\text {chl-cw }}$ increased) [10]. K-deficiency significantly increased cytoplasmic resistance of siliques by enhancing $D_{\text {chl-cw. Additionally, }}$ starch accumulation in silique chloroplasts under K-deficiency possibly enlarges chloroplast volume, resulting in enhanced stomatal resistance [18, 41]. Accordingly, silique $g_{\mathrm{m}}$ may be influenced by $\mathrm{K}$ supplies through anatomical variations. In addition to $\mathrm{CO}_{2}$ diffusion resistance, severe biochemical limitations on $\mathrm{CO}_{2}$ utilization may occur in K-starved organs by downregulating $J_{\max }$ and $V_{\text {cmax }}[13,16]$. As already noted, leaves were more sensitive to $K$ starvation with larger discrepancies in $J_{\max }$ and $V_{\text {cmax }}$ between the $-\mathrm{K}$ and $+\mathrm{K}$ treatment versus that of siliques. Furthermore, Kdeficiency is involved in the down-regulation of $\alpha$ and $\mathrm{Y}(\mathrm{II})$, and an attendant increase of energy dissipation $(\mathrm{Y}(\mathrm{NPQ}))$ in K-starved leaves and siliques, which is regarded as an efficient strategy to reduce photodamage [19]. Overall, these results collectively suggest that $K$ plays a crucial role in regulating leaf and silique photosynthesis through its influence on $\mathrm{CO}_{2}$ diffusion and biochemical limitations, with siliques exhibiting greater tolerance to $\mathrm{K}$ deficiency.

\section{Conclusions}

The present study demonstrated that the $\mathrm{CO}_{2}$ assimilation capacity of siliques was much weaker than that of leaves (only account for $35.0 \%$ ). It can be speculated that this difference is due to decreased function of photosynthetic apparatus, especially the integrated limitations of biochemical processes $\left(J_{\max }\right.$ and $\left.V_{\text {cmax }}\right)$ and $\alpha$. In comparison with leaves, siliques contained larger but fewer stomata, tightly packed cross-section with larger cells and fewer intercellular air spaces, fewer and smaller chloroplasts with thin grana lamellae. These anatomical traits might be linked to the reduced light capture and $\mathrm{CO}_{2}$ diffusion. K-deficiency profoundly decreased leaf and silique photosynthesis by down-regulating $g_{s}, \alpha$, $\mathrm{Y}(\mathrm{II}), \mathrm{CE}, V_{\mathrm{cmax}}$ and $J_{\max }$. Under K-starvation conditions, the most obvious anatomical features were the swollen chloroplasts with ubiquitous starch grains in silique cells 
but slightly ambiguous and irregularly arranged granum in leaf cells. Between two contrasting organs, siliques were more less vulnerable to $\mathrm{K}$-depletion, showing a lower decline in $\mathrm{K}$ concentration, $g_{\mathrm{s}}, V_{\mathrm{cmax}}, J_{\max }$, and $\mathrm{CO}_{2}$ diffusion resistance in the cytosol. Taken together, these results contribute to an understanding of silique photosynthesis and its response to K-deficiency.

\section{Methods}

\section{Study site and growth conditions}

This study was conducted during the 2014-2015 oilseed rape growing season on a $\mathrm{K}$ fertilization experiment located at Wuxue County, Hubei Province, central China $\left(30^{\circ} 06^{\prime} 46^{\prime \prime} \mathrm{N}, 115^{\circ} 36^{\prime} 9^{\prime \prime} \mathrm{E}\right)$. The location has a subtropical monsoon climate with mean whole-season and wintertide temperatures (from December 2014 to February 2015) of 12.2 and $6.5{ }^{\circ} \mathrm{C}$, respectively, and mean whole-season and wintertide precipitation of $670.0 \mathrm{~mm}$ and $222.4 \mathrm{~mm}$. The soil was a sandy loam with the following characteristics in the topsoil layer $(0-20 \mathrm{~cm})$ : $\mathrm{pH} 5.7$, organic matter $37.1 \mathrm{~g} \mathrm{~kg}^{-1}$, total $\mathrm{N} 2.0 \mathrm{~g} \mathrm{~kg}^{-1}, \mathrm{NH}_{4} \mathrm{OAc}-\mathrm{K}$ $45.3 \mathrm{mg} \mathrm{kg}^{-1}$, Olsen-P $14.6 \mathrm{mg} \mathrm{kg}^{-1}$ and hot-water soluble B $0.82 \mathrm{mg} \mathrm{kg}^{-1}$. According to the abundance and deficiency indices of soil-available $\mathrm{K}$ [23], the soil type is defined as K-deficient, which would cause yield reduction without the addition of $\mathrm{K}$ fertilizer.

\section{Experimental design}

The experiment was carried out in a complete randomized block design with two $\mathrm{K}$ treatments and four replicates. The treatments were: (1) sufficient $\mathrm{K}$ supply $(+\mathrm{K})$, with a rate of $120 \mathrm{~kg} \mathrm{~K}_{2} \mathrm{O} \mathrm{ha}{ }^{-1}$ (recommended for this region) [42]. (2) $\mathrm{K}$ deficiency $(-\mathrm{K})$, with no $\mathrm{K}$ fertilizer applied throughout the growing season.

Apart from K, plants received $180 \mathrm{~kg} \mathrm{~N} \mathrm{ha}{ }^{-1}, 90 \mathrm{~kg}$ $\mathrm{P}_{2} \mathrm{O}_{5} \mathrm{ha}^{-1}$, and $1.6 \mathrm{~kg} \mathrm{~B} \mathrm{ha}^{-1}$. Nitrogen (urea, 46\% N) was applied in three splits: $60 \%$ prior to transplanting, i.e., $\mathrm{BBCH}$ (Biologische Bundesantalt, Bundessortenamt and Chemische Industrie) 15-16 [43], 20\% at the overwintering stage (i.e., $\mathrm{BBCH} 29$ ), and $20 \%$ at the start of stem elongation (i.e., $\mathrm{BBCH} 30$ ). In addition, all $\mathrm{P}$ (superphosphate, $12 \% \mathrm{P}_{2} \mathrm{O}_{5}$ ), $\mathrm{K}$ (potassium chloride, $60 \%$ $\mathrm{K}_{2} \mathrm{O}$ ), and $\mathrm{B}$ (borax, 10.8\%) fertilizers were applied manually as basal fertilizers. The experimental field was plowed and leveled with a rotary tiller, and basal fertilizers were incorporated during the process. The plot measured $20 \mathrm{~m}^{2}$, with a length of $10 \mathrm{~m}$ and a width of $2 \mathrm{~m}$.

Rapeseed seedlings were grown from seed (Huayouza No.9) in a nursery for 4 weeks and planted by hand at five-leaf stage (i.e., $\mathrm{BBCH} 15-16,3-4 \mathrm{~g}$ dry weight plant ${ }^{-1}$ ) on 22 October 2014 in double rows spaced approximately $0.3 \mathrm{~m}$ apart, with $0.2-0.3 \mathrm{~m}$ between plants, corresponding to 112,500 plants $\mathrm{ha}^{-1}$. The oilseed rape was grown under rain-fed conditions. Weeds, pests and disease stresses were controlled by spraying herbicides, insecticides and fungicides according to the local habits so that no obvious weeds, insect pests, and diseases infestations occurred during the cropping season.

\section{Leaf and silique tagging}

In each plot, 40 uniform plants were tagged on 12 November 2014 (3 weeks after transplanting, i.e. $\mathrm{BBCH}$ 17 ), and halved for leaf and silique determination. Twenty leaves (corresponding to 20 plants) were tagged immediately after emergence (length approximately $1.5 \mathrm{~cm})$, and subjected to destructive and nondestructive analyses 20 days later (i.e., $\mathrm{BBCH} 19$ ) at the point of maximum leaf photosynthesis $[44,45]$. The rest of the plant were left until the start of flowering (i.e., BBCH 60-61). For each plant, two adjacent flower buds on the main raceme and opening during the same day were tagged; and approximately 5 days later they had developed into siliques. Siliques were used in experiments after 20 days of growth, when the maximum silique wall area and photosynthetic rate were reached [46].

\section{Gas exchange}

Tagged leaves and siliques were used for gas exchange measurements with a portable, open circuit, infrared gas analysis system (Li-6400, Li-Cor Inc., Lincoln, NE, USA). For each plant, one tagged leaf and two siliques were placed into a Standard Chamber equipped with a 6400-02 LED light source and a 6400-22 L Lighted Conifer Chamber equipped with a 6400-18 RGB light source. Net photosynthesis $(A)$ was analyzed for four tagged plants in each treatment in the late morning (10:00-14:00) at a saturating photosynthetic photon flux density (PPFD) of $1500 \mu \mathrm{mol} \mathrm{m}^{-2} \mathrm{~s}^{-1}$ (90\% red light and $10 \%$ blue light). The maintained under the following standardized conditions: $\mathrm{CO}_{2}$ concentration, $400 \mu \mathrm{mol}$ $\mathrm{mol}^{-1}$ air; flow rate, $500 \mu \mathrm{mol} \mathrm{s}{ }^{-1}$; temperature, $25 \pm$ $0.2{ }^{\circ} \mathrm{C}$; and relative humidity, $50-60 \%$. After equilibration to a steady-state, $A$, stomatal conductance $\left(g_{\mathrm{s}}\right)$, and intercellular $\mathrm{CO}_{2}$ concentration $\left(C_{\mathrm{i}}\right)$ were recorded. Recording data of siliques were corrected for the area because the chamber was not completely filled. Siliques were then halved into two valves (i.e. silique walls) along the replum, the valves were then flattened and mounted on black cardboard after removing the seeds and scanned digitally together with a green reference card $\left(25 \mathrm{~cm}^{2}\right)$ using an Epson ES-1200C scanner (Epson, Long Beach, CA, USA). The silique area was determined using Image-Pro Plus 4.5 software (National Institutes of Health, Bethesda, Maryland).

Light- and $\mathrm{CO}_{2}$-response curves were constructed for three leaves and six siliques (each replicate consisted of two siliques) which had been previously acclimated to 
saturating light conditions for $20 \mathrm{~min}$. For light-response curves, gas exchange was determined at 11 levels of PPFD, (2000, 1800, 1500, 1200, 1000, 800, 500, 200, 100, 50, $0 \mu \mathrm{mol} \mathrm{m} \mathrm{m}^{-2} \mathrm{~s}^{-1}$ ). Meanwhile, the $C_{\mathrm{a}}$ was maintained at $400 \mu \mathrm{mol} \mathrm{mol}^{-1}$ air. For $\mathrm{CO}_{2}$-response curves, the $C_{\mathrm{a}}$ in the chamber was adjusted across a series of concentrations $(400,300,200,100,50,400,600,800,1000$, 1200 , and $1500 \mu \mathrm{mol} \mathrm{CO} \mathrm{mol}^{-1}$ ) at a constant PPFD of $1500 \mu \mathrm{mol} \mathrm{m} \mathrm{m}^{-2} \mathrm{~s}^{-1}$. The temperature and relative humidity during analysis of light and $\mathrm{CO}_{2}$ responses were uniformly controlled at $25 \pm 0.2{ }^{\circ} \mathrm{C}$ and $50-60 \%$. In all cases, the parameters were recorded and the areas were corrected (for siliques only) after the gas exchange rate stabilized at the given $C_{\mathrm{a}}$ or PPFD. Apparent quantum yield $(\alpha)$ and carboxylation efficiency $(C E)$ were represented by the initial slope of the linear part of the light-response curve $\left(0 \leq \mathrm{PPFD} \leq 200 \mu \mathrm{mol} \mathrm{m} \mathrm{m}^{-2} \mathrm{~s}^{-1}\right)$ and the $\mathrm{CO}_{2}$-response curve $\left(0 \leq C_{\mathrm{i}} \leq 200 \mu \mathrm{mol} \mathrm{CO} \mathrm{Col}^{-1}\right)$.

According to Farquhar, von Caemmerer and Berry (1980; FVCB) photosynthesis model, the net photosynthetic rate is limited mainly by Rubisco carboxylation or by $\mathrm{RuBP}$ regeneration [25]. The intercellular $\mathrm{CO}_{2}$ concentration at which the transition from Rubisco to RuBP regeneration limitation occurs was calculated in R3.3.1 ( $\mathrm{R}$ core Team, 2016) using plantecophys package [47]. The maximum rate of RuBP carboxylation $\left(V_{\mathrm{cmax}}\right)$ and the maximum rate of $\mathrm{RuBP}$ regeneration $\left(J_{\max }\right)$ were also evaluated using the same $\mathrm{R}$ package.

\section{Chlorophyll fluorescence imaging}

Imaging of chlorophyll fluorescence parameters was performed immediately after gas exchange measurements using a MINI-Version Imaging-PAM (IMAG-MIN/B, Walz, Effeltrich, Germany), which can be used to assess image areas up to $2.4 \times 3.2 \mathrm{~cm}$. The instrument employs a bank of blue LEDs (peak wavelength $470 \mathrm{~nm}$ ) and a 1/ 3" CCD camera $(640 \times 480$ pixels $)$. Before experiments, intact leaves and siliques were adapted to the dark for at least $30 \mathrm{~min}$. Immediately before measurement, three leaves and siliques were excised with a razor blade and put into black bags to avoid light reflections. Images of the minimal fluorescence yield of dark-acclimated samples $\left(F_{\mathrm{o}}\right)$ were acquired at low frequencies of pulsemodulated measuring light, and the maximal fluorescence yield $\left(F_{\mathrm{m}}\right)$ was measured with an 800 ms saturation pulse. Samples were then exposed to actinic illumination, and images of the steady-state chlorophyll fluorescence $\left(F_{\mathrm{t}}\right)$ were captured. Subsequently, the maximal fluorescence yield under light $\left(F_{\mathrm{m}}^{\prime}\right)$ was measured during exposure to saturation pulse. The maximum quantum yield of PSII $\left(F_{\mathrm{v}} / F_{\mathrm{m}}\right)$, the effective quantum efficiency of PSII (Y(II)) and the quantum yield of light-induced non-photochemical fluorescence quenching
(Y(NPQ)) were calculated with Imaging-Win software (Walz, Effeltrich, Germany).

\section{Morpho-physiological traits}

Six leaves and twelve siliques per treatment were used to determine areas according to the aforementioned approach. Leaves and silique walls were oven dried to constant weight at $60{ }^{\circ} \mathrm{C}$, and dry mass per area $\left(M_{\mathrm{A}}\right)$ was calculated by dividing the weight of the dry matter by the area. The samples were then milled, and subsamples of $0.15 \mathrm{~g}$ were digested with $\mathrm{H}_{2} \mathrm{SO}_{4}-\mathrm{H}_{2} \mathrm{O}_{2}$ [48], before $\mathrm{K}$ concentration determination using a flame 321 photometer (M-410, Cole-Parmer, Chicago, IL, USA). Thereafter, another three leaves and six siliques (with seeds and septa removed) were cut into small segments (approximately $5 \mathrm{~mm})$. After extraction with $80 \%(\mathrm{v} / \mathrm{v})$ alcohol for $24 \mathrm{~h}$, chlorophyll concentration was determined using a UV-vis spectrophotometer (UV2102, Unico, China) after extracting with $80 \%(\mathrm{v} / \mathrm{v})$ alcohol for $24 \mathrm{~h}$ [49].

\section{Anatomical analysis}

Cross-sections of the leaves and siliques used for gas exchange measurements were prepared. Segments (approximately $1 \times 1 \mathrm{~mm}$ ) obtained from intercostal areas of fresh leaves and from the middle valves of siliques were fixed in $2.5 \%$ glutaraldehyde $(v / \mathrm{v})$ in $0.1 \mathrm{M}$ phosphate buffer $\left(\mathrm{pH} \mathrm{7.2)}\right.$ for $4 \mathrm{~h}$ at $4{ }^{\circ} \mathrm{C}$. Subsequently, the segments were post-fixed with $1 \%$ osmium tetroxide for $1 \mathrm{~h}$ at $25^{\circ} \mathrm{C}$. The samples were further dehydrated in a graded ethanol series, and embedded in Spurr's epoxy resin, before polymerization.

For the light microscope observation, samples were cut into $1 \mu \mathrm{m}$ transverse sections using a LKB-5 ultramicrotome 359 (LKB Co., Ltd., Uppsala, Sweden), and stained with $0.5 \%$ toluidine blue. Micrographs were captured at a magnification of $100 \times$ using a Nikon Eclipse E600 microscope equipped with a Nikon 5 MP digital microscope camera DS-Fi1 (Nikon Corporation, Kyoto, Japan). Four samples were analyzed per treatment for both leaves or siliques. For each sample, thickness of at least four cross-sections was measured. $M_{\mathrm{A}}$ is the product of leaf thickness and density [50], therefore leaf density was estimated by dividing $M_{\mathrm{A}}$ by thickness.

For the ultrastructural observations, ultrathin sections $(90 \mathrm{~nm})$ were examined using a transmission electron 360 microscope (H-7650, Hitachi, Japan) after staining with $2.5 \%$ uranyl acetate $(w / v)$ and lead citrate. The numbers of chloroplast in the leaf spongy tissue cells and mesocarp cells $(n \geq 30)$ were counted under the magnification of $5000 \times$. The corresponding chloroplast length $\left(L_{\mathrm{chl}}\right)$ and thickness $\left(T_{\mathrm{chl}}\right)$, and the chloroplast distance from the cell wall $\left(D_{\text {chl-cw }}\right)$ were measured for at least 30 randomly selected chloroplasts at a magnification 
of 25,000-30,000x. Chloroplast surface area $\left(S_{\text {chl }}\right)$ and volume $\left(V_{\text {chl }}\right)$ were calculated (assuming that the chloroplasts were ellipsoids) according to the Cesaro formula:

$$
\begin{aligned}
& S_{\mathrm{chl}}=4 \times \pi \times \sqrt[3]{\left(d \times e^{2}\right)^{2}} \\
& V_{\mathrm{chl}}=\frac{4}{3} \times \pi \times d \times e^{2}
\end{aligned}
$$

Where $d=0.5 \times L_{\mathrm{chl}}$; and $e=0.5 \times T_{\mathrm{chl}}$. The average distance of chloroplasts from the cell wall $\left(D_{\text {chl-cw }}, \mathrm{n} \geq 30\right)$ was determined according to the method described by Tomás et al. (2013) [36].

For stomatal trait determination, the leaf and silique segments $(5 \times 5 \mathrm{~mm})$ were fixed in $2.5 \%$ glutaraldehyde (v/v) at $4{ }^{\circ} \mathrm{C}$ for $2 \mathrm{~h}$. Segments were then washed twice in $0.1 \mathrm{M}$ phosphate buffer $(\mathrm{pH}$ 7.2) and, followed by dehydrated in a graded ethanol series. After further drying and spraying with gold, the treated segments were observed and photographed with a scanning electron microscope (JSM-5310LV, Jeol Co, Tokyo, Japan). The numbers of stomata in the lower epidermis and exocarp were counted at a magnification of $500 \times$, and the stomatal frequency $(n \geq 20)$ was calculated by dividing the stomata number by the area of the field of view. In addition, at least 50 randomly selected stomatas were selected to measure the length $\left(L_{\text {stomata }}\right)$ and width $\left(W_{\text {stomata }}\right)$ at a magnification of $3500 \times$. Assuming the stomatas were ellipsoids, the single stomatal pore area $\left(\mathrm{A}_{\text {stomata }}\right)$ would be given as:

$$
A_{\text {stomata }}=\frac{1}{4} \times \pi \times L_{\text {stomata }} \times W_{\text {stomata }}
$$

Therefore, the total stomatal pore area was the product of $\mathrm{A}_{\text {stomata }}$ and stomata frequency.

\section{Statistical analyses}

Descriptive statistical analyses were used for the measured parameters to obtain means and standard error (SE). All data were subjected to two-way analysis of variance (ANOVA) with SPSS 18.0 software (SPSS, Chicago, IL, USA). The differences between mean values were compared with Duncan's multiple range test; $P<0.05$ was considered to indicate statistical significance. Graphics were prepared using the ORIGINPRO 8.5 software (OriginLab Corporation, Northampton, MA, USA).

\section{Additional files}

Additional file 1: Illustration showing development progress of Brassica napus L. (PDF $434 \mathrm{~kb}$ )

Additional file 2: The gap between estimated and modeled (theoretical) values of silique under $\mathrm{K}$ deficiency $(-\mathrm{K})$ and $\mathrm{K}$ sufficient $(+\mathrm{K}$ ) conditions. (PDF $282 \mathrm{~kb}$ )
Additional file 3: The relationship between chlorophyll fluorescence of photosystem II-based electron transport rate (ETR) at saturating photosynthetic photon flux density (PPFD) of $1500 \mathrm{umol} \mathrm{m}^{-2} \mathrm{~s}^{-1}$ with LI-6400 XT equipped with an integrated leaf chamber fluorometer (LI-6400-40) and maximum rate of electron transport $\left(U_{\max }\right)$ estimated from $A-C_{\mathrm{i}}$ curve. (PDF $\left.411 \mathrm{~kb}\right)$

\section{Abbreviations}

A: Net photosynthetic rate; $\mathrm{C}_{\mathrm{a}}$ : Ambient $\mathrm{CO}_{2}$ concentration; CE: Carboxylation efficiency; Chl: Chloroplast concentration; $\mathrm{C}_{\mathrm{i}}$ : Intercellular $\mathrm{CO}_{2}$ concentration; $D_{\text {chl-cw: }}$ the distance between chloroplast and cell wall; $F_{0}$ : the minimal fluorescence yield of dark-acclimated samples; $F_{\mathrm{v}} / F_{\mathrm{m}}$ : the maximum quantum yield of PSII; $g_{\mathrm{m}}$ : Mesophyll conductance; $g_{\mathrm{s}}$ : Stomatal conductance; $J_{\max }$ : the maximum rate of electron transport; K: Potassium; LAl: Leaf area index; $M_{\mathrm{A}}$ : Dry mass per area; PAl: Pod area index; PPFD: Photosynthetic photon flux density; $S_{\text {chl: }}$ : Chloroplast surface area; $V_{\text {chl: }}$ Chloroplast volume; $V_{\text {cmax }}$ : the maximum rate of RuBP carboxylation; $Y(I I)$ : Actual photochemical efficiency of PSII; Y(NPQ): the quantum yield of light-induced non-photochemical fluorescence quenching; $a$ : Apparent quantum yield.

\section{Acknowledgments}

We thank Professor Dr. Chunlei Zhang and Associate Professor Dr. Ni Ma, Oil Crops Research Institute, Chinese Academy of Agricultural Sciences, China, for their excellent technical assistance with the application of MINI-Version Imaging-PAM.

\section{Funding}

This work was supported by the National Natural Science Foundation of China (31672231) and the earmarked fund for China Agriculture Research System (CARS-12). Publication costs of the article were covered by the Fundamental Research Funds for the Central Universities (2662016PY117). The funders have no role in the study design, data analysis and interpretation, and manuscript writing, but just provide the financial support.

\section{Availability of data and materials}

The datasets used and analysed during the current study are available from the corresponding author on reasonable request.

\section{Author's contributions}

ZFL, SWG, TR and JWL conceived and designed the experiments; ZFL, YHP and WSH performed the experiments; ZFL and TR analyzed the data and wrote the paper; $\mathrm{RHC}$ helped in analysis of the results and manuscript writing; all authors discussed the results and reviewed the manuscript. All authors read and approved the final manuscript.

Ethics approval and consent to participate Not applicable.

\section{Consent for publication}

Not applicable.

\section{Competing interests}

The authors declare that they have no competing interests.

\section{Publisher's Note}

Springer Nature remains neutral with regard to jurisdictional claims in published maps and institutional affiliations.

\section{Author details}

${ }^{1}$ Collge of Resources and Environment, Huazhong Agricultural University, Key Laboratory of Arable Land Conservation (Middle and Lower Reaches of Yangtze River) Ministry of Agriculture, Shizishan Street 1, Wuhan 430070, People's Republic of China. ${ }^{2}$ Jiangsu Provincial Key Lab for Organic Solid Waste Utilization, National Engineering Research Center for Organic-based Fertilizers, Jiangsu Collaborative Innovation Center for Solid Organic Waste Resource Utilization, Nanjing Agricultural University, Nanjing 210095, People's Republic of China. 


\section{Received: 14 August 2017 Accepted: 1 December 2017}

Published online: 11 December 2017

\section{References}

1. Makino A. Photosynthesis, grain yield, and nitrogen utilization in rice and wheat. Plant Physiol. 2011;155:125-9.

2. Kalachanis D, Manetas Y. Analysis of fast chlorophyll fluorescence rise (O-K-J-I-P) curves in green fruits indicates electron flow limitations at the donor side of PSII and the acceptor sides of both photosystems. Physiol Plantarum. 2010;139:313-23.

3. Kong LG, Wang FH, Feng B, Li SD, Si JS, Zhang B. The structural and photosynthetic characteristics of the exposed peduncle of wheat (Triticum aestivum L.): an important photosynthate source for grain-filling. BMC Plant Biol. 2010;10:141.

4. Yiotis C, Manetas Y. Sinks for photosynthetic electron flow in green petioles and pedicels of Zantedeschia aethiopica: evidence for innately high photorespiration and cyclic electron flow rates. Planta. 2010;232:523-31.

5. Kobayashi K, Sasaki D, Noguchi K, Fujinuma D, Komatsu H, Kobayashi M, et al. Photosynthesis of root chloroplasts developed in Arabidopsis lines overexpressing GOLDEN2-LIKE transcription factors. Plant Cell Physiol. 2013; 54:1365-77.

6. Bennett EJ, Roberts JA, Wagstaff $C$. The role of the pod in seed development: strategies for manipulating yield. New Phytol. 2011;190: 838-53.

7. Pettigrew WT. Potassium influences on yield and quality production for maize, wheat, soybean and cotton. Physiol Plantarum. 2008:133:670-81.

8. Zörb C, Senbayram M, Peiter E. Potassium in agriculture-status and perspectives. J Plant Physiol. 2014;171:656-69.

9. Lu ZF, Lu JW, Pan YH, Li XK, Cong RH, Ren T. Genotypic variation in photosynthetic limitation responses to $\mathrm{K}$ deficiency of Brassica napus is associated with potassium utilisation efficiency. Funct Plant Biol. 2016;43: 880-91.

10. Lu ZF, Lu JW, Pan YH, Lu PP, Li XK, Cong RH. Anatomical variation of mesophyll conductance under potassium deficiency has a vital role in determining leaf photosynthesis. Plant Cell Environ. 2016:39:2428-39.

11. Aschan G, Pfanz H. Non-foliar photosynthesis-a strategy of additional carbon acquisition. Flora. 2003;198:81-97.

12. Jákli B, Tavakol E, Tränkner M, Senbayram M, Dittert K. Quantitative limitations to photosynthesis in K deficient sunflower and their implications on water-use efficiency. J Plant Physiol. 2017;209:20-30.

13. Jin SH, Huang JQ, Li XQ, Zheng BS, Wu JS, Wang ZJ, Liu GH, Chen M. Effects of potassium supply on limitations of photosynthesis by mesophyll diffusion conductance in Carya cathayensis. Tree Physiol. 2011:31:1142-51.

14. Battie-Laclau P, Laclau JP, Beri C, Mietton L, Muniz MRA, Arenque BC. Photosynthetic and anatomical responses of Eucalyptus grandis leaves to potassium and sodium supply in a field experiment. Plant Cell Environ. 2014:37:70-81.

15. Terashima I, Hanba YT, Tholen D, Niinements Ü. Leaf functional anatomy in relation to photosynthesis. Plant Physiol. 2011;155:108-16.

16. Lu ZF, Ren T, Pan Y, Li XK, Cong RH, Lu JW. Differences on photosynthetic limitations between leaf margins and leaf centers under potassium deficiency for Brassica napus L. Sci Rep. 2016;6:21725.

17. Wagstaff C, Yang TJW, Stead AD, Buchanan-Wollaston V, Roberts JA. A molecular and structural characterization of senescing Arabidopsis siliques and comparison of transcriptional profiles with senescing petals and leaves. Plant J. 2009:57:690-705.

18. Zhao D, Oosterhuis DM, Bednarz CW. Influence of potassium deficiency on photosynthesis, chlorophyll content, and chloroplast ultrastructure of cotton plants. Photosynthetica. 2001;39:103-9.

19. Weng $X Y$, Zheng $C J, X u H X$, Sun JY. Characteristics of photosynthesis and functions of the water-water cycle in rice (Oryza sativa) leaves in response to potassium deficiency. Physiol Plantarum. 2007;131:614-21.

20. Gabrielle B, Denoroy P, Gosse G, Justes E, Andersen MN. Development and evaluation of a CERES-type model for winter oilseed rape. Field Crop Res. 1998;57:95-111.

21. Diepenbrock W. Yield analysis of winter oilseed rape (Brassica napus L.): a review. Field Crop Res. 2000;67:35-49.

22. Kuai J, Sun YY, Zuo QS, Huang HD, Liao QX, Wu CY, et al. The yield of mechanically harvested rapeseed (Brassica napus L.) can be increased by optimum plant density and row spacing. Sci Rep. 2015;5:18835.
23. Zou J, Lu JW, Li YS, Li XK. Regional evaluation of winter rapeseed response to $\mathrm{K}$ fertilization, $\mathrm{K}$ use efficiency, and critical level of soil $\mathrm{K}$ in the Yangtze River valley. Sci Agric Sin. 2011;10:911-20.

24. Aschan G, Pfanz H, Vodnik D, Batic F. Photosynthesis performance of vegetative and reproductive structures of green hellebore (Helleborus viridis L. agg.). Photosynthetic. 2005;43:55-64.

25. Farquhar GD, von Caemmerer S, Berry JA. A biochemical model of photosynthetic $\mathrm{CO}_{2}$ assimilation in leaves of $\mathrm{C}_{3}$ species. Planta. 1980;149:78-90.

26. Yamori W, Nagai T, Makino A. The rate-limiting step for $\mathrm{CO}_{2}$ assimilation at different temperatures is influenced by the leaf nitrogen content in several $\mathrm{C}_{3}$ crop species. Plant Cell Environ. 2011;34:764-77.

27. Evans JR, Sharkey ED, Berry JA, Farquhar GD. Carbon isotope discrimination measured concurrently with gas exchange to investigate $\mathrm{CO}_{2}$ diffusion in leaves of higher plants. Aust J Plant Physiol. 1986;13: 281-92.

28. Vogelmann TC, Evans JR. Profiles of light absorption and chlorophyll within spinach leaves from chlorophyll fluorescence. Plant Cell Environ. 2002;25: 1313-23.

29. Pribil M, Labs M, Leister D. Structure and dynamics of thylakoids in land plants. J Exp Bot. 2014;65:1955-72.

30. Yang N, Zhang Y, Halpert JE, Zhai J, Wang D, Jiang L. Granum-like stacking structures with $\mathrm{TiO} 2-$ graphene nanosheets for improving photo-electric conversion. Small. 2012;8:1762-70.

31. King SP, Badger MR, Furbank RT. $\mathrm{CO}_{2}$ refixation characteristics of developing canola seeds and silique wall. Funct Plant Biol. 1998;25: 377-86.

32. Atkins CA, Kuo J, Pate JS, Flinn AM, Steele TW. Photosynthetic pod wall of pea (Pisum sativum L.) distribution of carbon dioxide-fixing enzymes in relation to pod structure. Plant Physiol. 1977;60:779-86.

33. Carrara S, Pardossi A, Soldatini GF, Tognoni F, Guidi L. Photosynthetic activity of ripening tomato fruit. Photosynthetica. 2001;39:75-8.

34. Long SP, Bernacchi CJ. Gas exchange measurements, what can they tel us about the underlying limitations to photosynthesis? Procedures and sources of error. J Exp Bot. 2003:54:2393-401.

35. Furbank RT, White R, Palta JA, Turner NC. Internal recycling of respiratory $\mathrm{CO} 2$ in pods of chickpea (Cicer arietinum L.): the role of pod wall, seed coat, and embryo. J Exp Bot. 2004;55:1687-96.

36. Tomás M, Flexas J, Copolovici L, Galmés J, Hallik L, Medrano H, et al. Importance of leaf anatomy in determining mesophyll diffusion conductance to $\mathrm{CO}_{2}$ across species: quantitative limitations and scaling up by models. J Exp Bot. 2013;64:2269-81.

37. Battie-Laclau P, Laclau JP, Piccolo MDC, Arenque BC, Beri C, Mietton L, et al. Influence of potassium and sodium nutrition on leaf area components in Eucalyptus grandis trees. Plant Soil. 2013;371:19-35.

38. Karley AJ, White PJ. Moving cationic minerals to edible tissues: potassium, magnesium, calcium. Curr Opin Plant Biol. 2009;12:291-8.

39. Bednarz CW, Oosterhuis DM, Evans RD. Leaf photosynthesis and carbon isotope discrimination of cotton in response to potassium deficiency. Environ Exp Bot. 1998:39:131-9.

40. Tosens T, Nishida K, Gago J, Coopman RE, Cabrera HM, Carriquí M, et al. Photosynthetic capacity in 35 ferns and fern allies: mesophyll $\mathrm{CO}_{2}$ diffusion as a key trait. New Phytol. 2015;209:1576-90.

41. Hall JD, Barr R, Al-Abbas AH, Crane FL. The ultrastructure of chloroplasts in mineral-deficient maize leaves. Plant Physiol. 1972;50:404-9.

42. Li YS, Lu JW, Zou J, Li XK, Huang HP, Yu Y, et al. Study on response to potassium (K) application and recommendation of optimal $K$ rates for rapeseed in Hubei. Chin J Oil Crop Sci. 2008;30:469-75.

43. Lancashire PD, Bleiholder $H$, Boom TVD, Langelüddeke P, Stauss R, Weber E, et al. A uniform decimal code for growth stages of crops and weeds. Ann Appl Biol. 1991;119:561-601.

44. Gammelvind LH, Schjoerring JK, Mogensen VO, Jensen CR, Bock JGH. Photosynthesis in leaves and siliques of winter oilseed rape (Brassica napus L.). Plant Soil. 1996;186:227-36.

45. Jensen CR, Mogensen VO, Mortensen G, Andersen MN, Schjoerring JK, Thage $\mathrm{JH}$, Koribidis J. Leaf photosynthesis and drought adaption in fieldgrown oilseed rape (Brassica napus L.). Aust J Plant Physiol. 1996:23:631-44.

46. Hua W, Li RJ, Zhan GM, Liu J, Li J, Wang XF, Liu GH, Wang HZ. Maternal control of seed oil content in Brassica napus: the role of silique wall photosynthesis. Plant J. 2012;69:432-44.

47. Duursma RA. Plantecophys-an R package for analysing and modelling leaf gas exchange data. PLoS One. 2015;10:e0143346. 
48. Thomas RL, Sheard RW, Moyer JR. Comparison of conventional and automated procedures for nitrogen, phosphorus, and potassium analysis of plant material using a single digestion. Agron J. 1967;59:240-3.

49. Arnon DI. Copper enzymes in isolated chloroplast: polyphenoloxidase in Beta vulgaris. Plant Physiol. 1949;24:1-15.

50. Witkowski ETF, Lamont BB. Leaf specific mass confounds leaf density and thickness. Oecologia. 1991;88:486-93.

Submit your next manuscript to BioMed Central and we will help you at every step:

- We accept pre-submission inquiries

- Our selector tool helps you to find the most relevant journal

- We provide round the clock customer support

- Convenient online submission

- Thorough peer review

- Inclusion in PubMed and all major indexing services

- Maximum visibility for your research

Submit your manuscript at www.biomedcentral.com/submit
Biomed Central 